\title{
Enhancing Access to Bank Credit for Small-Scale Farmers in Kisumu and Kiambu Districts, Kenya Through Public-Private Partnership Initiative
}

\author{
Charles M. Rambo \\ University of Nairobi, Kenya
}

\begin{abstract}
In Kenya, small-scale farming has immense potential in poverty reduction. The growth of farming activities requires sustainable access to affordable credit to boost and sustain production. This study is initiated to investigate factors influencing access to bank credit by small-scale farmers in Kisumu and Kiambu Districts, Kenya. It is necessitated by lack of a comprehensive study documenting the effectiveness of the partnership initiative in improving access to credit for small-scale farmers. The study seeks to address the following concerns: what factors influence access to bank credit by small-scale farmers under the initiative? Are small-scale farmers in various parts of the country accessing bank credit equally? Through which sources do farmers get to know about credit products provided through the initiative? Primary data was collected from 144 farmers in Kiambu and 127 farmers in Kisumu, sampled using systematic random procedure. The cross-sectional survey design was applied to guide the research process. Quantitative analysis generated cross-tabulations with chi-square and binary logistic regression. The study found that out of 144 credit applicants in Kiambu about 56.3\% were successful, while in Kisumu only 37.8\% were successful. Access to bank credit was significantly associated with farmers' gender, education level, income level, farm size, and farming experience. Besides, women were 1.3 times less likely to access bank credit than men. In terms of regional variation, a Kiambu farmer was 2.7 times more likely to obtain bank credit than a Kisumu farmer. The initiative is an innovative approach for enhancing access to bank credit; however, its potential has not been fully exploited. The study recommends the need: to inform farmers about credit products to clear misconceptions and myths associated with bank credit; develop innovative financing packages for small-scale farmers that are also gender-sensitive; and to initiate a training program targeting farmers with appropriate information.
\end{abstract}

Keywords: access to bank credit, small-scale farming, public-private partnership, commercial banks, government, credit request

\section{Introduction}

The Kenyan economy is largely founded on agriculture, contributing up to 25 percent of the national Gross Domestic Product (GDP) and provides employment opportunities to over 75 percent of the national workforce.

Charles M. Rambo, Ph.D., Department of Extra Mural Studies, University of Nairobi.

Correspondence concerning this article should be addressed to Charles M. Rambo, P.O. Box 30197-00100, NAIROBI, Kenya. E-mail: rambocharles@yahoo.com. 
Small-scale farming accounts for 75 percent of the total agricultural output and about 70 percent of marketed agricultural produce (Kibaara, 2006; Government of Kenya, 2010). The Agricultural Sector Development Strategy (ASDS) in 2010-2011 defined small-scale farmers as those undertaking their production in farms averaging 0.2 to 3 hectares, mainly for commercial purposes. Based on this, small-scale farmers produce over 70 percent of maize, 65 percent of coffee, 50 percent of tea, 80 percent of milk, 85 percent of fish, and 70 percent of beef and related products (Government of Kenya, 2010).

Various empirical studies, including Stamoulis (2007) and World Bank (2008) noted that the growth of small-scale agricultural sub-sector was the primary source of poverty reduction, particularly in developing economies. In this regard, the expansion of small-scale farming has a great potential to reduce poverty by increasing incomes of farmers and reducing expenditure on food (Stamoulis, 2007; World Bank, 2008). According to Ravallion (2001) an increase in household income by 2 percent translates to a fall in poverty level by about 4 percent on average. Besides, the GDP growth originating from agricultural sector is about four times more effective in reducing poverty than GDP growth of other sectors (World Bank, 2008). Thus, the growth of small-scale farming has immense potential in alleviating poverty and reducing hunger in line with the Millennium Development Goal (MDG) number one.

\section{Access to Bank Credit and the Growth of Small-Scale Farming}

The growth of small-scale farming requires sustainable access to affordable credit facilities to boost and sustain production. Although all business ventures, including farming require capital to grow and realize their potential, small-scale farming in Kenya has not received adequate support from the banking sector, as regards access to credit facilities (Kibaara, 2006). Similarly, Odhiambo (2007) noted that Kenyan commercial banks had shied away from providing credit to small-scale farmers due to the high risk of agricultural activities, resulting from erratic weather conditions. At the continental level, a study conducted by FAO noted that Africa agriculture accounts for only 2 percent of the commercial credit, a situation that undermined agricultural sector's contribution to poverty eradication in the continent's fragile economies (FAO, 2004). Small-scale farmers are by-passed by credit facilities provided by commercial banks for lack of collateral and credit history (Pearce, 2004).

A World Bank study also confirms that commercial banks have not been responsive to the financing needs of agricultural ventures due to inherent risks. As a result, the share of credit provided to the sector by commercial banks has been lower compared with the proportion that goes to manufacturing, trade and other service sectors. This continues to impede expansion and technology adoption (World Bank, 2008). Most small-scale farmers have been coping by depending on savings from low incomes, while some farmers rely on credits provided by their friends, relatives, and informal money lenders. Limited access to formal credit facilities limit the ability of small-scale farmers to realize their potential (Pearce, 2004; Kibaara, 2005).

\section{Government's Effort to Enhance Access to Formal Credit for Small-Scale Farmers}

The need to improve access to formal credit facilities for small-scale farmers dates back to 1963, when the Agricultural Finance Corporation (AFC) was established as subsidiary of the Land and Agricultural Bank. The institution was later incorporated as a fully-fledged financial institution in 1969 through the Agricultural Finance Corporation Act, Cap 323, laws of Kenya in 1969 (Mwangi, 2008). Its primary mandate was to assist the development of agricultural sector by providing credit products designed to meet the needs of farmers, as well as 
providing technical support to beneficiaries of its credit facilities (AFC, 2008). Although AFC has been instrumental in meeting the financing needs of small-scale farmers over the years, poor governance led to about one-third (27\%) of its credit portfolio being non-performing (AFC, 2008). Its optimal performance is also undermined by low interest rates compared, which has seen the Corporation lose up to KES 1.4 billion in a span of five years due to subsidised interest rates. Worse still, the corporation is highly undercapitalized, operating at a credit portfolio of KES 3.8 billion, instead of the recommended KES 10 billion (AFC, 2008). This necessitates alternative ways through which the government can reach small-scale farmers in a more cost-effective way (Mwangi, 2008).

The need to improve access to formal credit for small-scale farmers is also recognized in national policy documents, including the Economic Recovery Strategy for Wealth and Employment Creation (ERSWEC) in 2003-2007, which underscored the government's concern about poor access to credit services as a key factor undermining agricultural productivity. Access to credit by small-scale farmers is also resonated in the sectoral policy document - the Strategy for Revitalizing Agriculture (SRA) and ASDS. The policy documents articulate a series of corrective interventions, including enacting appropriate legislation to encourage microfinance institutions to come up with appropriate lending policies for small-scale farmers; creating conducive business environment to make farming more rewarding; incentivizing commercial banks to increase lending to the agricultural sector; and recapitalizing and streamlining the management of AFC to fulfill its mandate (Government of Kenya, 2004, 2010; Kibaara, 2006). In July 2003, African Heads of States congregated in Maputo, Mozambique during the Second Ordinary Session to discuss important development issues bedeviling the continent (African Union, 2003). The meeting came up with various declarations among them, the need to increase budgetary allocation to the agricultural sector to at least 10 percent of the national budgets, as well as initiate mechanisms for enhancing access to credit by small-scale farmers by the end of 2008 (African Union, 2003; New Partnership for African Development, 2009).

The partnership initiative with selected commercial banks is an idea that was inspired by aforethought policy recommendations, spanning over several years. The partnership initiative, which involved two commercial banks-Equity Bank (Equity) and the Cooperative Bank of Kenya (Coop), which have been financed by the GoK and development partners such as Alliance for a Green Revolution in Africa (AGRA) and the International Fund for Agricultural Development (IFAD), among others (World Bank, 2008; ASARECA, 2010). The two commercial banks were identified as financial intermediaries, channeling funds to reach more than 2.5 million small-scale farmers and about 15,000 agricultural value chain members such as rural input shops, fertilizers and seed wholesalers and importers, grain traders, and food processors (ASARECA, 2010).

\section{Effectiveness of the Partnership Initiative With Commercial Banks}

The partnership initiative was formalized through a memoranda of understanding (MoU), which created a leeway for the intermediary banks to set up and modify, as appropriate, credit management policies (ASARECA, 2010). Although no comprehensive study has ever assessed the effectiveness of the partnership initiative in addressing financing needs of small-scale farmers, a few anecdotal literature highlight that access to credit under the initiative is pegged on farmers availing suitable collateral, which most of them cannot afford, providing information about their credit record, which locks out most farmers (Odhiambo, 2007; ASARECA, 2010). 
Additional concerns emerging in anecdotal literature include the tendency of commercial banks not to adhere to the terms spelt out in the MoU. In this regard, the banks are accused of prioritizing lending out their own funds, which to them, is more profitable (Kandinate, 2007) and altering interest rates for funds advanced through the partnership initiative. For instance, interest rate for the Kilimo Biashara was set at 1 percent per month; however, this was raised to 15 percent, which was prohibitive to small-scale farmers (ASARECA, 2010).

Another concern is the lag between request and approval for credit, which has serious implications for the utilisation of credit for agricultural purposes, where timely investment is critical for success (Kibaara, 2006; ASARECA, 2010). In addition, there is limited awareness on the part of farmers about the initiative and related credit products provided by the commercial banks, a situation, which the policy brief by ASARECA (2010) attributes to inadequate dissemination of information about the partnership initiative and its benefits to small-scale farmers. Kandinate (2007) also affirmed that most small-scale farmers were not aware of available agricultural credit facilities, while some farmers had phobic about bank credit, others believed that banks provide credit to people with huge account balances.

\section{Statement of the Problem}

The role of small-scale farming in the realization of the first MDG on poverty alleviation and hunger reduction by 2015 is well-documented (Ravallion, 2001; Government of Kenya, 2003, 2004, 2010; Kibaara, 2005; Stamoulis, 2007; World Bank, 2008). Nonetheless, small-scale farming requires sustainable access to affordable credit to boost and sustain production (Pearce, 2004; ASARECA, 2010; Odhiambo, 2007; Kandinate, 2007). Although commercial banks play a key role in supporting economic development in various sectors, most of them have shied away from financing small-scale farmers due to prohibitive collateral requirement, lack of credit record, high interest rates, and high risks associated with farming vis-à-vis climatic patterns (FAO, 2004; Pearce, 2004; Kibaara, 2006; Odhiambo, 2007; World Bank, 2008). To cope with the situation, small-scale farmers depend on their savings and informal credits provided by friends, relatives and money lenders, as well as self-help groups and farmers' cooperatives, but which barely suffice their financing needs (Pearce, 2004; Odhiambo, 2007; Kandinate, 2007). The partnership initiative between GoK and selected commercial banks is among various interventions aimed at improving access to formal credits for at least 2.5 million small-scale farmers. Although no comprehensive study has been undertaken to assess the extent to which small-scale farmers are accessing bank credit under the partnership initiative, a few anecdotal literature hint that access to bank credit has not improved for most farmers as earlier envisage. Farmers are still required to raise collateral and provide credit track record.

Furthermore, commercial banks prefer to lend out their own funds, which attract higher interest rates, they have also failed to adhere to provisions of the $\mathrm{MoU}$ formalizing the partnership initiative, particularly as regards interest rates (Kibaara, 2006; Odhiambo, 2007). Other concerns emerging in the literature include the long duration between the time requests are made and the time credit is disbursed, which affects the timing of investments, because most small-scale farmers rely on rain-fed agriculture (Kibaara, 2006; ASARECA, 2010). Also raising concern is the limited awareness about credit services provided by banks involved in the partnership initiative due to inadequate dissemination of information about the initiative (ASARECA, 2010). Against this background of challenges, the study seeks to address the following concerns: what factors influence the access to 
bank credit by small-scale farmers under the partnership initiative? Are small-scale farmers in various parts of the country accessing bank credit equally? Through which sources do farmers get to know about credit products provided by banks involved in the initiative? The need to address these concerns prompted the conduct of this study. Kiambu and Kisumu Districts were particularly selected because of their distinct variation in development indicators, particularly incomes per capita and longevity (United Nations Development Programme and Government of Kenya, 2008).

\section{Objectives of the Study}

The broad objective of the study was to assess factors influencing access to bank credit by small-scale farmers under the partnership initiative. Specifically, the study addressed the following objectives:

(1) Assess the relationships between farmers' profile and access to bank credit;

(2) Establish the sources of information about credit services provided by the partnership initiative;

(3) Determine the factors influencing access to bank credit among small-scale farmers;

(4) Assess regional variation in access to bank credit by small-scale farmers.

\section{Hypotheses of the Study}

The study determined the statistical significance of the following null hypotheses:

$\mathrm{H}_{0} 1$ : The success of credit request is not significantly related to gender.

$\mathrm{H}_{0}$ 2: The success of credit request is not significantly associated with age of farmers.

$\mathrm{H}_{0} 3$ : The success of credit request and marital status are not significantly related.

$\mathrm{H}_{0} 4$ : There is no significant relationship between the success of credit request and family size.

$\mathrm{H}_{0} 5$ : Credit request success and education level are not significantly related.

$\mathrm{H}_{0} 6$ : There is no significant link between the success of credit request and religion.

$\mathrm{H}_{0} 7$ : The success of credit request is not significantly associated with usual place of residence.

$\mathrm{H}_{0} 8$ : Credit request success and income level are not significantly related.

$\mathrm{H}_{0} 9$ : There is no significant association between the success of credit request and land tenure.

$\mathrm{H}_{0} 10$ : The relationship between the success of credit request and land size is not significant.

$\mathrm{H}_{0} 11$ : There is no significant link between the success of credit requests and farming experience.

$\mathrm{H}_{0} 12$ : The success of credit request and type of farming are not significantly associated.

$\mathrm{H}_{0} 13$ : The success of credit request and number of previous requests are not significantly related.

\section{Research Design}

The study applied cross-sectional survey designs with both quantitative and qualitative approaches. Whereas the information sourced through quantitative approach was used for descriptive and inferential purposes, the qualitative approach obtained in-depth information based on experiences and opinions of bank staff members. Cross-sectional surveys cross-analyze baseline information of participants, including demographic, social and economic attributes, as well as perceptions and attitudes (American Statistical Association, 1999). As noted by Rindfleisch, Malter, Ganesan \& Moorman (2008) cross-sectional survey designs are cheaper than longitudinal designs and are less vulnerable to intervening factors such as social, political or cultural changes that may occur during the life of a project, which may affect the validity of information sourced. 


\section{Research Method}

Primary data were collected from small-scale farmers in Kiambu and Kisumu Districts between May and July 2009. They included farmers who had applied for bank credit within a period of six months, that is, between September 2008 and March 2009. The farmers were identified through credit request records provided by the banks. Using the records, systematic random sampling was preformed to give every farmer an equal opportunity for selection. The sampling process yielded a total of 178 farmers in Kiambu and 152 farmers in Kisumu District. However, by the end of July 2009, only 144 and 127 interviews were successful in Kiambu and Kisumu Districts, respectively. This gives a response rate of 80.9 percent and 83.6 percent in Kiambu and Kisumu, respectively. Selected farmers were traced to their homes from where they were interviewed using a semi-structured questionnaire. Primary data were also obtained from six staff members of the banks, who were selected purposively based on their direct involvement in credit services to small-scale farmers. The interviews were guided by a key informant interview schedule, which sourced qualitative data.

Both quantitative and qualitative analysis techniques were used in the study. While quantitative analysis generated cross-tabulations with chi-square and binary logistic regression, the qualitative component elicited qualitative information based on the opinions and experiences of bank staff, who were interviewed as key informants. Binary logistic regression is often used to predict the proportion of variation in a dichotomous variable from a set of independent and confounding variables (Aldrich \& Nelson, 1984). When applying the model, the predicted variable takes the value 1 with a probability of success $\theta$, or the value 0 with probability of failure 1- $\theta$. In this study, the dependent variable was success of credit request (CREDRsucc), with only two possible values - successful or unsuccessful. The model is often expressed as indicated below (Aldrich \& Nelson, 1984):

$$
\text { Logit }[\theta(Y)]=\log \left(\frac{\theta(Y)}{1-\theta(Y)}\right)=\alpha+\beta_{1} X_{1}+\beta_{2} X_{2}+\beta_{3} X_{3}+\ldots+\beta_{i} X_{i}+\varepsilon
$$

Where: $Y=$ the predicted variable (CREDRsucc); $\theta(Y)=$ the probability that the credit request was successful; $1-\theta(Y)=$ the probability that credit request was unsuccessful; $\alpha=$ the constant term of the equation; $\beta_{1}, \beta_{2} \ldots \beta_{i}=$ the regression co-efficients associated with independent variables; $X_{1}, X_{2} \ldots X_{i}=$ independent variables; and $\varepsilon=$ the error term. Although the model has several output parameters, this study was interested in the $\operatorname{Exp}(\beta)$ or odds ratios. The Statistical Package for Social Sciences (SPSS) and Microsoft Excel packages were used to facilitate quantitative analyses.

Figure 1 shows the conceptual framework used in the study. The conceptual framework presented shows that access to bank credit under the partnership initiative is a function of a set of factors, which can conceptually be categorized as socio-economic, farming attributes, and demographic factors.

However, the magnitude and direction of effect between the independent variables and the dependent variables is likely to be confounded by a set of intervening variables such as district of residence, banking institution and number of times one has applied for credit, among others. Table 1 provides the operational definition of the variables outlined in the conceptual framework. 


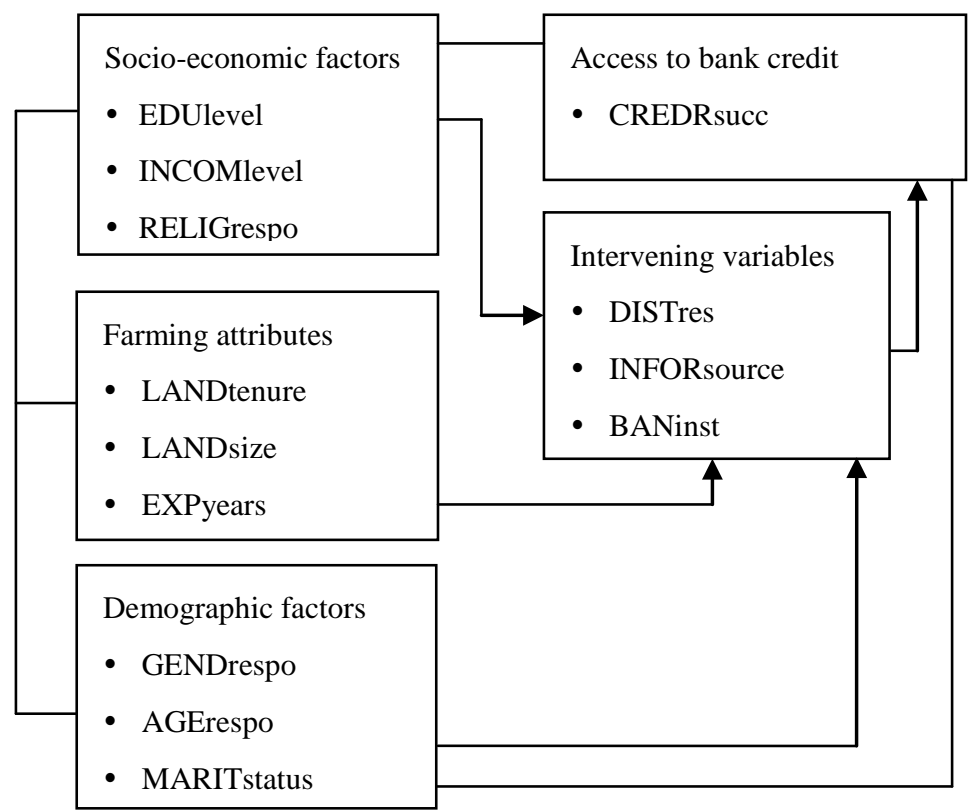

Figure 1. Conceptual framework.

Table1

Operational Definition of Variables Used in the Equation

\begin{tabular}{|c|c|c|}
\hline Variable & Full name & Value labels \\
\hline GENDrespo & Respondent's gender & $\begin{array}{l}1 \text {-men } \\
2 \text {-women }\end{array}$ \\
\hline AGErespo & Age of respondents & $\begin{array}{l}1-20-29 \text { years } \\
2-30-39 \text { years } \\
3-40-49 \text { years } \\
4-50-59 \text { years } \\
5-60 \text { years }+\end{array}$ \\
\hline EDUlevel & Highest education level & $\begin{array}{l}\text { 1-no education } \\
\text { 2-primary } \\
\text { 3--secondary } \\
\text { 4-college } \\
\text { 5-university }\end{array}$ \\
\hline INCOMlevel & Average monthly income & $\begin{array}{l}\text { 1-KES 20,000 } \\
\text { 2-KES 20,000-39,999 } \\
\text { 3-KES 40,000-59,999 } \\
\text { 4-KES 60,000-79,999 } \\
\text { 5-KES 80,000-99,999 } \\
\text { 6-KES 100,000-149,999 } \\
\text { 7-KES 150,000+ }\end{array}$ \\
\hline LANDtenure & Land ownership type & $\begin{array}{l}\text { 1-owns land singly } \\
\text { 2-owns land jointly with family } \\
\text { 3-owns land jointly with non-family } \\
\text { 4-rented land }\end{array}$ \\
\hline LANDsize & Size of land & $\begin{array}{l}1-\text { less than } 1 \text { ha } \\
2-1.0 \text { to } 1.4 \text { ha } \\
3-1.5 \text { to } 1.9 \text { ha } \\
4-2.0 \text { to } 2.4 \text { ha } \\
5-2.5 \text { to } 2.9 \text { ha }\end{array}$ \\
\hline EXPyears & Farming experience & $\begin{array}{l}1-\text { less than } 5 \text { years } \\
2-5-9 \text { years } \\
3-10-14 \text { years } \\
4-15 \text { years }+\end{array}$ \\
\hline
\end{tabular}


(Table 1 continued)

\begin{tabular}{|c|c|c|}
\hline Variable & Full name & Value labels \\
\hline MARITstatus & Respondent’s marital status & $\begin{array}{l}\text { 1-single } \\
\text { 2-married } \\
\text { 3-divorced/separated } \\
\text { 4-widowed }\end{array}$ \\
\hline FAMILYsize & Number of children owned by respondent & $\begin{array}{l}\text { 1-no children } \\
2-1-4 \text { children } \\
3-5-9 \text { children } \\
4-10 \text { children+ }\end{array}$ \\
\hline RELIGrespo & Religion of the respondent & $\begin{array}{l}\text { 1-protestant } \\
\text { 2-catholic } \\
\text { 3-muslim } \\
\text { 4-others } \\
\text { 5-no religion }\end{array}$ \\
\hline DISTres & District of residence & $\begin{array}{l}\text { 1-kiambu } \\
\text { 2-kisumu }\end{array}$ \\
\hline INFORsource & Most important source of information on bank credit & $\begin{array}{l}\text { 1-bank } \\
\text { 2-ASK show } \\
\text { 3-friends } \\
\text { 4-family } \\
\text { 5-public forums }\end{array}$ \\
\hline BANinst & Banking institution & $\begin{array}{l}\text { 1—equity bank } \\
2 \text {-coorpertaive bank }\end{array}$ \\
\hline NUMapplied & Number of times applied for credit & $\begin{array}{l}\text { 1-ones } \\
\text { 2-twice } \\
\text { 3-thrice } \\
\text { 4-more than thrice }\end{array}$ \\
\hline CREDRsucc & Success of credit request & $\begin{array}{l}\text { 1-successful } \\
\text { 2-unsuccessful }\end{array}$ \\
\hline
\end{tabular}

Qualitative data were processed and analyzed following three steps. In the first step, data were organized and summarized in line with key thematic areas. The second step involved description of the summary sheets to produce a preliminary report. The third step involved systematic analysis and interpretation of the preliminary report, which was then integrated with quantitative data in the final report (Best \& Khan, 2004).

\section{Study Findings}

This section presents findings of the study, which have been organized under four thematic headings, including background profile of farmers, information sources on bank credit, factors influencing access to bank credit, and model's goodness-of-fit. Details have been discussed in the following sub-sections.

\section{Background Profile of Farmers and Access to Bank Credit}

The study covered a total of 271 small-scale farmers who had applied for bank credit between September 2008 and March 2009, of which 144(53.1\%) were residents of Kiambu and 127(46.9\%) resided in Kisumu District. Of the 271 respondents, only 129(47.6\%) credit applicants were successful; the rest, 142(52.4\%) were unsuccessful. In Kiambu, 56.3 percent of the 144 applicants were successful, while in Kisumu, only 37.8 percent were successful. Bivariate analysis obtained a calculated $\chi^{2}$ of 8.489 (corrected for continuity), with 1 degree of freedom and a $p$-value of 0.004 . The result is significant at 0.01 error margin, implying up to 99 percent chances that the two districts were significantly different in terms of the success of bank credit request.

\section{Demographic Profile}

Table 2 shows that out of 129 successful credit applicants, up to 86.8 percent were men. The analysis 
obtained a calculated $\chi^{2}$ of 18.024 (corrected for continuity), with 1 degree of freedom and a $p$-value of 0.000 , which is significant at 0.01 error margin. This implies up to 99 percent chances that the success of credit request was significantly associated with genders, which negates the null hypothesis $\left(\mathrm{H}_{0} 1\right)$ stating that the success of credit request is not significantly related to gender. Consequently, $\mathrm{H}_{0} 1$ was rejected for being inconsistent with empirical findings.

Table 2

Demographic Profile and Access to Bank Credit

\begin{tabular}{|c|c|c|c|c|}
\hline \multirow{2}{*}{ Variables } & \multicolumn{2}{|l|}{ Successful } & \multicolumn{2}{|c|}{ Not successful } \\
\hline & Frequency & Percent & Frequency & Percent \\
\hline \multicolumn{5}{|l|}{ Gender } \\
\hline Men & 112 & 86.8 & 79 & 55.6 \\
\hline Women & 17 & 13.2 & 63 & 44.4 \\
\hline Total & 129 & 100.0 & 142 & 100.0 \\
\hline \multicolumn{5}{|l|}{ Age } \\
\hline 20-29 years & 12 & 9.3 & 16 & 11.3 \\
\hline 30-39 years & 36 & 27.8 & 33 & 23.2 \\
\hline 40-49 years & 42 & 32.6 & 53 & 37.4 \\
\hline 50-59 years & 30 & 23.3 & 31 & 21.8 \\
\hline 60 years + & 9 & 7.0 & 9 & 6.3 \\
\hline Total & 129 & 100.0 & 142 & 100.0 \\
\hline \multicolumn{5}{|l|}{ Marital status } \\
\hline Single & 2 & 1.6 & 2 & 1.4 \\
\hline Married & 110 & 85.2 & 111 & 78.2 \\
\hline Divorced/separated & 13 & 10.1 & 3 & 2.1 \\
\hline Widowed & 4 & 3.1 & 26 & 18.3 \\
\hline Total & 129 & 100.0 & 142 & 100.0 \\
\hline \multicolumn{5}{|l|}{ Family size } \\
\hline No children & 7 & 5.4 & 6 & 4.2 \\
\hline 1-4 children & 43 & 33.3 & 54 & 38.1 \\
\hline 5-9 children & 74 & 57.4 & 71 & 50.0 \\
\hline 10 children + & 5 & 3.9 & 11 & 7.7 \\
\hline Total & 129 & 100.0 & 142 & 100.0 \\
\hline
\end{tabular}

Note. Source: Survey Data, 2009.

As regarding age, about one-third (32.6\%) of the successful credit applicants were in the 40-49 years age bracket, 27.9 percent were aged 30-39 years, while 23.3 percent were in the bracket of 50-59 years. The analysis further obtained a calculated $\chi^{2}$ of 1.371 , with four degrees of freedom and a $p$-value of 0.849 , which is not significant. This implies that the success of credit request has no significant link with applicants' age, thus, the null hypothesis $\left(\mathrm{H}_{0} 2\right)$ stating that the success of credit request is not significantly associated with age of farmers was not rejected for lack of sufficient empirical evidence to warrant its rejection.

The results show that 85.3 percent of the 129 successful credit applicants were married at the time of the study, while 10.1 percent were divorced or separated. The analysis obtained calculated $\chi^{2}$ of 21.814 , with three degrees of freedom and a p-value of 0.000 , which is significant at 0.01 error margin, implying up to 99 percent chances that the success of credit application was significantly associated with applicants' marital status. This 
prompted rejection of the null hypothesis $\left(\mathrm{H}_{0} 3\right)$ stating that the success of credit request and marital status are not significantly related. As for family size, out of 129 successful credit applicants, 57.4 percent had between five and 9 children, while about one third (33.3\%) had one to four children. The analysis obtained a calculated $\chi^{2}$ of 3.020 , with three degrees of freedom and a p-value of 0.389 , which is not significant, thus, the null hypothesis $\left(\mathrm{H}_{0} 4\right)$ stating that there is no significant relationship between the success of credit request and family size was rejected.

\section{Socio-Economic Profile}

The results presented in Table 3 show that of the 129 successful credit applicants, 33.3 percent had attained university education, while 30.2 percent had college education. The analysis yielded a calculated $\chi^{2}$ of 32.413 , with four degrees of freedom and a p-value of 0.000 , which is significant at 0.01 error margin. This implies up to 99 percent chances that the success of credit request was significantly linked to applicants' education level, prompting the rejection of the null hypothesis $\left(\mathrm{H}_{0} 5\right)$ stating that the success of credit request and education level are not significantly related.

The main religious affiliations of the 129 successful credit applicants include Protestantism (47.3\%) and Catholicism (34.1\%). The analysis obtained a calculated $\chi^{2}$ of 2.512, with four degrees of freedom and a p-value of 0.643 , which is not significant. This implies that the success of credit request was not significantly associated with applicants' religious background, hence, the null hypothesis $\left(\mathrm{H}_{0} 6\right)$ stating that there is no significant link between the success of credit request and religion was not rejected. In addition, majority (89.9\%) of the 129 successful credit applicants, were rural dwellers. The analysis further obtained a calculated $\chi^{2}$ of 1.426 , with one degree of freedom (corrected for continuity) and a p-value of 0.514 . However, the result is not significant, an indication that the success of credit applications is not significantly linked to applicants' usual place of residence. Again, the null hypothesis $\left(\mathrm{H}_{0} 7\right)$ stating that the success of credit request is not significantly associated with usual place of residence was not rejected.

As regarding income level, the results in Table 3 show that out of 129 successful credit applicants, up to 27.9 percent were in the KES 60,000-79,000 income bracket, while 22.5 percent were earning between KES 40,000 and 59,999 . The analysis further yielded a calculated $\chi^{2}$ of 14.912 , with six degrees of freedom and a p-value of 0.001 , which is significant at 0.01 error margin. This gives up to 99 percent chances that the success of credit requests was significantly tied to applicants' income level. As a result, the null hypothesis $\left(\mathrm{H}_{0} 8\right)$ stating that credit request success and income level are not significantly related was rejected. The study also found that up to 81.4 percent of the 129 successful credit applicants owned land singly, while 13.2 percent owned land jointly with family members. Bivariate analysis between the success of credit request and land tenure obtained a calculated $\chi^{2}$ of 6.929, with three degrees of freedom and a p-value of 0.051 , which is significant at 0.1 error margin. This implies up to 90 percent chances that the success of credit request was significantly associated with the types of land tenure. The result prompted the rejection of the null hypothesis $\left(\mathrm{H}_{0} 9\right)$, which stated that there was no significant association between the success of credit request and land tenure. 
Table 3

Socio-Economic Profile and Access to Bank Credit

\begin{tabular}{|c|c|c|c|c|}
\hline \multirow{2}{*}{ Variables } & \multicolumn{2}{|l|}{ Successful } & \multicolumn{2}{|c|}{ Not successful } \\
\hline & Frequency & Percent & Frequency & Percent \\
\hline \multicolumn{5}{|l|}{ Education level } \\
\hline No education & 2 & 1.6 & 4 & 2.8 \\
\hline Primary & 10 & 7.8 & 37 & 26.1 \\
\hline Secondary & 35 & 27.1 & 69 & 48.6 \\
\hline College & 39 & 30.2 & 25 & 17.6 \\
\hline University & 43 & 33.3 & 7 & 4.9 \\
\hline Total & 129 & 100.0 & 142 & 100.0 \\
\hline \multicolumn{5}{|l|}{ Religion } \\
\hline Protestant & 61 & 47.3 & 74 & 52.1 \\
\hline Catholic & 44 & 34.1 & 51 & 35.9 \\
\hline Muslim & 5 & 3.9 & 3 & 2.1 \\
\hline Others & 17 & 13.2 & 12 & 8.5 \\
\hline No religion & 2 & 1.5 & 2 & 1.4 \\
\hline Total & 129 & 100.0 & 142 & 100.0 \\
\hline \multicolumn{5}{|l|}{ Usual place of residence } \\
\hline Rural & 116 & 89.9 & 123 & 86.6 \\
\hline Urban & 13 & 10.1 & 19 & 13.4 \\
\hline Total & 129 & 100.0 & 142 & 100.0 \\
\hline \multicolumn{5}{|l|}{ Income level } \\
\hline$<$ KES 20,000 & 8 & 6.2 & 20 & 14.1 \\
\hline KES 20,000-39,999 & 13 & 10.1 & 26 & 18.3 \\
\hline KES 40,000-59,000 & 29 & 22.5 & 32 & 22.5 \\
\hline KES 60,000-79,000 & 36 & 27.9 & 38 & 26.8 \\
\hline KES 80,000-99,999 & 24 & 18.6 & 17 & 12.0 \\
\hline KES $100,000-149,000$ & 16 & 12.4 & 6 & 4.2 \\
\hline KES $150,000+$ & 3 & 2.3 & 3 & 2.1 \\
\hline Total & 129 & 100.0 & 142 & 100.0 \\
\hline \multicolumn{5}{|l|}{ Land ownership type } \\
\hline Owns land singly & 105 & 81.4 & 80 & 56.3 \\
\hline Owns land jointly with family & 17 & 13.2 & 41 & 28.9 \\
\hline Owns land jointly with non-family & 6 & 4.6 & 15 & 10.6 \\
\hline Rented land & 1 & 0.8 & 6 & 4.2 \\
\hline Total & 129 & 100.0 & 142 & 100.0 \\
\hline
\end{tabular}

Note. Source: Survey data, 2009.

Furthermore, Table 4 shows that out of the 129 successful credit applicants, up to 35.7 percent had between 2.5 and 2.9 hectares (ha) of land, while 32.6 percent had 2.0 to 2.4 ha. In total, about 68 percent of the successful credit applicants had at least 2 ha of land. The analysis obtained a calculated $\chi^{2}$ of 16.865 , with four degrees of freedom and a $p$-value of 0.025 , which is significant at 0.05 error margin, implying up to 95 percent chances that the success of credit request was significantly associated with the size of land owned by applicants. This necessitated the rejection of the null hypothesis $\left(\mathrm{H}_{0} 10\right)$, stating that the relationship between the success of credit request and land size is not significant. 
Table 4

Economic Attributes and Access to Bank Credit

\begin{tabular}{|c|c|c|c|c|}
\hline \multirow{2}{*}{ Variables } & \multicolumn{2}{|l|}{ Successful } & \multicolumn{2}{|c|}{ Not successful } \\
\hline & Frequency & Percent & Frequency & Percent \\
\hline \multicolumn{5}{|l|}{ Land size } \\
\hline $0.2-0.9$ ha & 9 & 7.0 & 47 & 33.1 \\
\hline $1.0-1.4$ ha & 13 & 10.1 & 39 & 27.5 \\
\hline 1.5-1.9 ha & 19 & 14.6 & 23 & 16.2 \\
\hline 2.0-2.4 ha & 42 & 32.6 & 22 & 15.5 \\
\hline 2.5-2.9 ha & 46 & 35.7 & 11 & 7.7 \\
\hline Total & 129 & 100.0 & 142 & 100.0 \\
\hline \multicolumn{5}{|c|}{ Years of farming experience } \\
\hline$<5$ years & 13 & 10.1 & 61 & 43.0 \\
\hline 5-9 years & 27 & 20.9 & 44 & 31.0 \\
\hline 10-14 years & 38 & 29.5 & 33 & 23.2 \\
\hline 15 years + & 51 & 39.5 & 4 & 2.8 \\
\hline Total & 129 & 100.0 & 142 & 100.0 \\
\hline \multicolumn{5}{|l|}{ Type of farming } \\
\hline Crop farming & 78 & 60.5 & 30 & 21.1 \\
\hline Animal farming & 32 & 24.8 & 25 & 17.6 \\
\hline Mixed farming & 19 & 14.7 & 87 & 61.3 \\
\hline Total & 129 & 100.0 & 142 & 100.0 \\
\hline \multicolumn{5}{|c|}{ No. of times applied for credit } \\
\hline Once & 17 & 13.2 & 51 & 35.9 \\
\hline Twice & 29 & 22.5 & 35 & 24.6 \\
\hline Thrice & 35 & 27.1 & 24 & 16.9 \\
\hline More than thrice & 48 & 37.2 & 32 & 22.5 \\
\hline Total & 129 & 100.0 & 142 & 100.0 \\
\hline
\end{tabular}

The study also revealed that farmers had various levels of farming experience. In this regard, out of 129 successful credit applicants, up to 39.5 percent had 15 years or more of farming experience, while about one-third (29.5\%) had 10 to 14 years experience. The analysis yielded a calculated $\chi^{2}$ of 22.038 , with three degrees of freedom and a p-value of 0.002 . The result is significant at 0.01 error margin, implying up to 99 percent chances that the success of credit request was significantly associated with applicants' farming experience. Based on the result, the null hypothesis $\left(\mathrm{H}_{0} 11\right)$ stating that there is no significant link between the success of credit request and farming experience was rejected due to inconsistency with empirical findings.

Table 4 also shows that up to 60.5 percent of the successful credit applicants were crop farmers, while 24.8 percent specialized in livestock farming. Further analysis obtained a calculated $\chi^{2}$ of 2.752 , with two degrees of freedom and a p-value of 0.687, which is not significant. This suggests that the success of credit requests is not significantly associated with farming types practiced by an individual. Thus, the null hypothesis $\left(\mathrm{H}_{0} 12\right)$ which stated that the success of credit request and type of farming are not significantly associated was not rejected. More still, up to 37.2 percent of the 129 successful credit applicants had applied for credit more than thrice, while 27.1 percent had done so three times. The analysis further yielded a calculated $\chi^{2}$ of 5.146, with three degrees of freedom and a p-value of 0.052 , which is significant at 0.1 error margin. This gives up to 90 percent chances that the success of credit application is significantly associated with the number of previous credit requests made to 
the intermediary banks. Hence, the null hypothesis $\left(\mathrm{H}_{0} 13\right)$ which stated that the success of credit request and the number of previous requests are not significantly related was rejected.

\section{Information Sources and Access to Bank Credit by Farmers}

Lack of information on credit products offered by commercial banks is highlighted in the literature as a key impediment to small-scale farmers in accessing bank credit facilities. In view of this, the study assessed the extent to which Kiambu and Kisumu farmers were accessing information through mass media, particularly radios, televisions (TV), and newspapers. Figure 2 shows that out of 271 farmers, 48.3 percent listened to radios, 38.0 percent watched TV, and 17.0 percent read newspapers on a daily basis. Descriptive statistics further show that radio is the most important form of mass media that was accessible to farmers, followed by TV and newspapers.

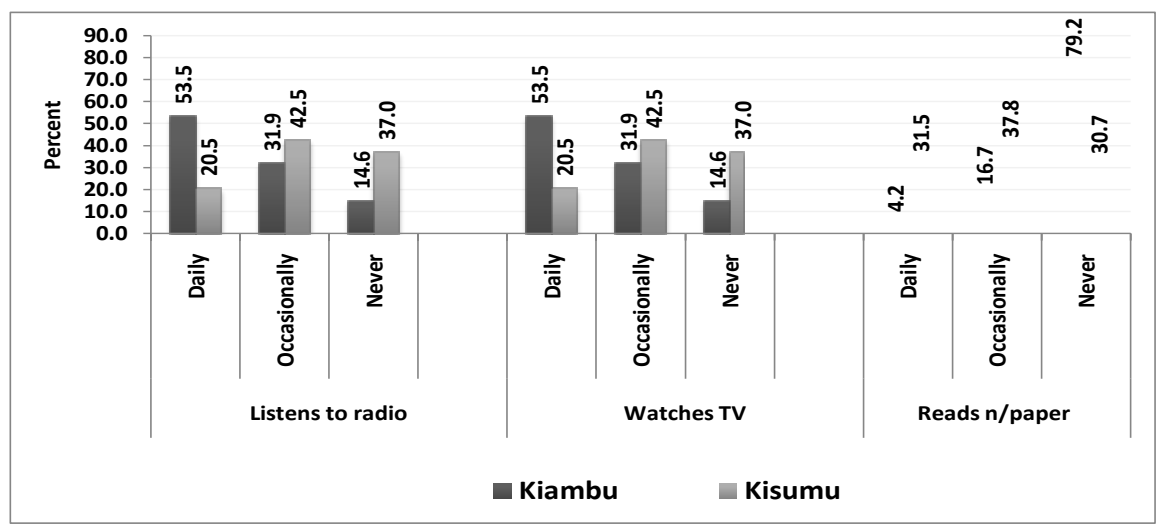

Figure 2. Access to mass media by small-scale farmers.

In terms of regions, daily radio listeners and TV watchers were more in Kiambu than in Kisumu, while daily newspaper readers were more in Kisumu than Kiambu. For radio listenership, bivariate analysis obtained a calculated $\chi^{2}$ of 6.923 , with two degrees of freedom and a $p$-value of 0.031 , which is significant at 0.05 error margin. This implies that small-scale farmers in Kiambu and Kisumu districts were significantly different in terms of radio listening behavior. For TV watching, the analysis yielded a calculated $\chi^{2}$ of 34.905 , with two degrees of freedom and a $p$-value of 0.000 , which is significant at 0.01 error margin. This finding suggests that farmers in the two districts were significantly different in terms of TV watching behavior, thus, were less likely to have equal access to information disseminated through TV. As for newspaper reading, the analysis obtained a calculated $\chi^{2}$ of 69.101 , with two degrees of freedom and a $p$-value of 0.000 . The result is significant at 0.01 error margin, implying up to 99 percent chances that farmers in the two districts were different in terms of newspaper reading. Overall, the results suggest that small-scale Kiambu farmers had greater access to mass media than Kisumu farmers, hence, were likely to be more informed about bank credit facilities.

In relation to credit access, Figure 3 shows that among farmers whose credit request were successful, 46.5 percent listened to radio daily, while 45.7 percent were occasional listeners. Besides, 40.3 percent of the farmers whose credit request were successful watched TV daily, while 19.4 percent were daily readers of newspapers. Based on the linkage between the frequency of radio listerning and access to bank credit, the analysis obtained a calculated $\chi^{2}$ of 2.341, with two degrees of freedom and a $p$-value of 0.310 , which is not significant. This shows lack of a significant difference between frequent radio listeners and non-listeners in terms of the success of credit 
request. As for TV watching, the analysis obtained a calculated $\chi^{2}$ of 2.274, with two degrees of freedom and a $p$-value of 0.321 , again, which is not significant. This suggests that frequent TV watchers were not significantly different from non-watchers in terms of the success of credit requests.

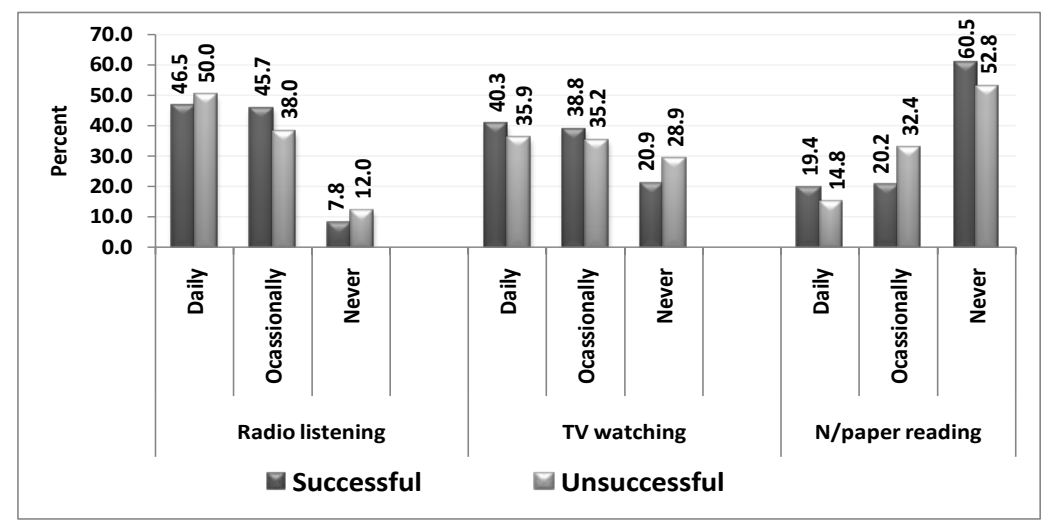

Figure 3. Mass media and access to bank credit.

The analysis for newspaper reading and credit access yielded a calculated $\chi^{2}$ of 5.351, with two degrees of freedom and a $p$-value of 0.069 , which is significant at 0.1 error margin. This implies up to 90 percent chances that frequent newspaper readers and non-readers were significantly different in terms of the success of credit request. However, when asked to state the most common source of information about credit services offered by the intermediary banks, none of the respondents cited radio, TV or newspaper. In this regard, Figure 4 shows that out of 271 participants, 32.5 percent obtained information from Agricultural Society of Kenya (ASK) shows; 26.9 percent knew about the credit services through friends, while 19.6 percent learnt through the banks.

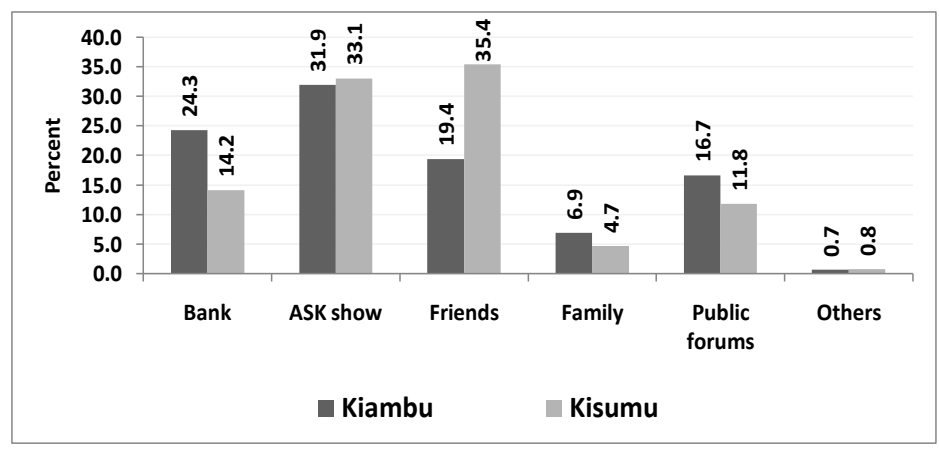

Figure 4. Main sources of information about bank credit.

Bivariate analysis obtained a calculated $\chi^{2}$ of 11.650 , with five degrees of freedom and a $p$-value of 0.040 , which is significant at 0.05 error margin. This suggests up to 95 percent chances that farmers in the two districts were significantly different in terms of the main source of information about credit facilities provided by the intermediary commercial banks. More specifically, in Kisumu, the most important sources of information included friends (35.4\%), ASK shows (33.9\%), and banks (14.2\%), while in Kiambu, main information sources included ASK shows (31.9\%), Banks (24.3\%), and friends (19.4\%). The analysis further assessed the nature of association between main sources of information and the success of credit request by the farmers. The results presented in Table 4 show that among the 129 successful participants, 29.5 percent received information from 
ASK shows, 27.1 percent were informed by friends, while 23.3 percent knew about credit facilities through banks.

Table 5

Information Sources and Access to Bank Credit

\begin{tabular}{lcccc}
\hline Sources of information & Successful & & Not successful & Percent \\
\hline Bank & Frequency & Percent & Frequency & 16.2 \\
ASK show & 30 & 23.3 & 23 & 35.2 \\
Friends & 38 & 29.4 & 50 & 26.8 \\
Family & 35 & 27.1 & 38 & 7.7 \\
Public forums & 5 & 3.9 & 11 & 12.7 \\
Others & 21 & 16.3 & 18 & 1.4 \\
Total & 0 & 0.0 & 2 & 100.0 \\
\hline
\end{tabular}

The analysis obtained a calculated $\chi^{2}$ of 6.556 , with five degrees of freedom and a $p$-value of 0.256 . This result is not significant, suggesting lack of a significant linkage between the main source of information about credit facilities provided by the intermediary commercial banks and the success of credit request. Although the participants indicated awareness of the credit facilities provided by the intermediary banks, the study found that this knowledge was in the possession of very few farmers. Most small-scale farmers lacked the information, thus, had not made any attempt to access bank credit provided under the partnership initiative.

\section{Factors Influencing Access to Bank Credit Access by Farmers}

Bivariate analysis revealed that the success of credit request significantly associated with various factors, including gender, marital status, education level, income level, type of land tenure, land size, farming experience and number of times one has applied for credit. These variables were entered into binary logistic regression models to determine their effects on the success of credit request by small-scale farmers. The results are summarized in Table 6.

Gender. In first model, credit requests by men were about 1.7 times more likely to succeed than credit requests by women. The variation between men and women is significant at 0.05 error margin. In the second model, where potential confounders were added to the equation, credit requests by men were about 1.3 times more likely to succeed than requests made by women. Again, the variation between the two groups is significant at 0.01 error margin, implying up to 99 percent chances that men had greater chances of accessing bank credit than women. The variation between men and women in accessing bank credit was stronger in Kisumu District than in Kiambu. More specifically, the results indicated that Kiambu women were about 4.3 times more likely to have successful credit request than Kisumu women. However, Kisumu men were about 0.5 times less likely to have successful credit applications than Kiambu men, the variation was not significant.

Education level. In model one, the results show that credit request by university graduates were about 2.1 times more likely to succeed than request made by farmers with no formal education. When the model is adjusted for confounders, university graduates became 1.4 times more likely to have their requests successful than applicants with no formal education. Variation between the two groups is significant at 0.01 error margin. Generally, the results show that the probability to have successful credit request varies directly as applicants' 
education level. In terms of regions, the results indicated that Kiambu farmers holding university degrees were about 0.8 times more likely to have successful credit request than Kisumu farmers with the same education level. However, variation between the two groups was not significant. In addition, Kiambu farmers with no formal education were about 1.4 times more likely to have successful credit request than their Kisumu counterparts. The difference between the two groups is significant at 0.05 error margin, implying up to 95 percent chances that uneducated farmers in Kiambu had better access to bank credit than their counterparts in Kisumu.

Table 6

Summary Results of Binary Logistic Regression

\begin{tabular}{|c|c|c|c|c|c|c|c|c|}
\hline \multirow{2}{*}{ Covariates } & \multicolumn{4}{|l|}{ Model 1} & \multicolumn{4}{|l|}{ Model 2} \\
\hline & $\beta$ & S.E. & $p$ & $\operatorname{Exp}(\beta)$ & $\beta$ & S.E. & $p$ & $\operatorname{Exp}(\beta)$ \\
\hline \multicolumn{9}{|l|}{ GENDrespo } \\
\hline Men & 0.558 & 0.312 & $0.043^{* *}$ & 1.747 & 0.272 & 0.211 & $0.001^{*}$ & 1.313 \\
\hline Women (RC) & $\operatorname{xxxx}$ & $\mathrm{xxxx}$ & $\mathrm{xxxx}$ & $\operatorname{xxxx}$ & $\mathrm{xxxx}$ & $\operatorname{xxxx}$ & $\operatorname{xxxx}$ & $\mathrm{xxxx}$ \\
\hline \multicolumn{9}{|l|}{ EDUlevel } \\
\hline University & 0.716 & 0.558 & $0.002^{*}$ & 2.046 & 0.353 & 0.249 & $0.007^{*}$ & 1.423 \\
\hline College & 0.301 & 0.538 & $0.048^{* *}$ & 1.351 & 0.176 & 0.166 & $0.014^{* *}$ & 1.192 \\
\hline Secondary & 0.056 & 0.656 & $0.021^{* *}$ & 1.058 & 0.037 & 0.052 & $0.035^{* *}$ & 1.038 \\
\hline Primary & 0.033 & 0.136 & $0.057^{* * *}$ & 1.034 & 0.017 & 0.214 & 0.122 & 1.017 \\
\hline No Education (RC) & $\mathrm{xxxx}$ & $\operatorname{xxxx}$ & $\operatorname{xxxx}$ & $\mathrm{xxxx}$ & $\mathrm{xxxx}$ & $\operatorname{xxxx}$ & $\operatorname{xxxx}$ & $\mathrm{xxxx}$ \\
\hline \multicolumn{9}{|l|}{ INCOMlevel } \\
\hline KES $150,000+$ & 0.993 & 0.157 & $0.000^{*}$ & 2.699 & 0.846 & 0.111 & $0.000^{*}$ & 2.330 \\
\hline KES 100,000-149,999 & 0.720 & 0.125 & $0.000^{*}$ & 2.054 & 0.711 & 0.046 & $0.000^{*}$ & 2.036 \\
\hline KES 80,000-99,999 & 0.624 & 0.118 & $0.021^{* *}$ & 1.866 & 0.563 & 0.123 & $0.025^{* *}$ & 1.756 \\
\hline KES 60,000-79,999 & 0.278 & 0.325 & $0.027^{* *}$ & 1.320 & 0.344 & 0.312 & $0.013^{* *}$ & 1.411 \\
\hline KES 40,000-59,999 & 0.141 & 0.248 & 0.112 & 1.151 & 0.155 & 0.253 & $0.045^{* *}$ & 1.168 \\
\hline KES 20,000-39,999 & 0.138 & 0.212 & 0.244 & 1.148 & 0.139 & 0.231 & 0.247 & 1.149 \\
\hline$<$ KES 20,000 (RC) & $\operatorname{xxxx}$ & $\operatorname{xxxx}$ & $\operatorname{xxxx}$ & $\operatorname{xxxx}$ & $\operatorname{xxxx}$ & $\operatorname{xxxx}$ & $\operatorname{xxxx}$ & $\operatorname{xxxx}$ \\
\hline \multicolumn{9}{|l|}{ LANDtenure } \\
\hline Owns land singly & 0.769 & 0.301 & $0.035^{* *}$ & 2.158 & 0.645 & 0.232 & $0.017^{* *}$ & 1.906 \\
\hline Owns land jointly with family & 0.153 & 0.346 & $0.036^{* *}$ & 1.165 & 0.142 & 0.460 & $0.009^{*}$ & 1.153 \\
\hline Owns land jointly with non-family & 0.043 & 0.443 & 0.145 & 1.044 & 0.031 & 0.464 & $0.029^{* *}$ & 1.031 \\
\hline Rented land (RC) & $\operatorname{xxxx}$ & $\operatorname{xxxx}$ & $\operatorname{xxxx}$ & $\operatorname{xxxx}$ & $\operatorname{xxxx}$ & $\operatorname{xxxx}$ & $\operatorname{xxxx}$ & $\operatorname{xxxx}$ \\
\hline \multicolumn{9}{|l|}{ LANDsize } \\
\hline 2.5-2.9 ha & 0.463 & 0.417 & $0.001^{*}$ & 1.589 & 0.440 & 0.386 & $0.000^{*}$ & 1.553 \\
\hline 2.0-2.4 ha & 0.449 & 0.494 & $0.006^{*}$ & 1.567 & 0.415 & 0.363 & $0.001^{*}$ & 1.514 \\
\hline 1.5-1.9 ha & 0.285 & 0.455 & $0.033^{* *}$ & 1.330 & 0.231 & 0.232 & $0.028^{* *}$ & 1.260 \\
\hline $1.0-1.4$ ha & 0.172 & 0.384 & 0.125 & 1.188 & 0.112 & 0.226 & 0.103 & 1.119 \\
\hline$<1.0$ ha $(\mathrm{RC})$ & $\operatorname{xxxx}$ & $\operatorname{xxxx}$ & $\operatorname{xxxx}$ & $\operatorname{xxxx}$ & $\mathrm{xxxx}$ & $\operatorname{xxxx}$ & $\operatorname{xxxx}$ & $\operatorname{xxxx}$ \\
\hline \multicolumn{9}{|l|}{ EXPyears } \\
\hline 15 years+ & 0.422 & 0.217 & $0.013^{* *}$ & 1.525 & 0.440 & 0.338 & $0.002^{*}$ & 1.402 \\
\hline $10-14$ years & 0.192 & 0.249 & $0.025^{* *}$ & 1.212 & 0.415 & 0.328 & $0.000^{*}$ & 1.388 \\
\hline 5-9 years & 0.113 & 0.219 & $0.033^{* *}$ & 1.120 & 0.231 & 0.258 & $0.012^{* *}$ & 1.294 \\
\hline < 5 years $(\mathrm{RC})$ & $\operatorname{xxxx}$ & $\operatorname{xxxx}$ & $\operatorname{xxxx}$ & $\operatorname{xxxx}$ & $\mathrm{xxxx}$ & $\operatorname{xxxx}$ & $\operatorname{xxxx}$ & $\operatorname{xxxx}$ \\
\hline \multicolumn{9}{|l|}{ MARITstatus } \\
\hline Single & -0.421 & 0.221 & $0.065^{* * *}$ & 0.656 & -0.533 & 0.137 & $0.032^{* *}$ & 0.587 \\
\hline Married & 0.724 & 0.295 & $0.000^{*}$ & 2.063 & 0.891 & 0.234 & $0.000^{*}$ & 2.438 \\
\hline Divorced/separated & -0.537 & 0.211 & 0.243 & 0.584 & -0.642 & 0.264 & 0.141 & 0.526 \\
\hline
\end{tabular}


(Table 6 continued)

\begin{tabular}{|c|c|c|c|c|c|c|c|c|}
\hline \multirow{2}{*}{ Covariates } & \multicolumn{4}{|c|}{ Model 1} & \multicolumn{4}{|c|}{ Model 2} \\
\hline & $\beta$ & S.E. & $p$ & $\operatorname{Exp}(\beta)$ & $\beta$ & S.E. & $p$ & $\operatorname{Exp}(\beta)$ \\
\hline Widowed (RC) & $\operatorname{xxxx}$ & $\mathrm{xxxx}$ & $\operatorname{xxxx}$ & $\mathrm{xxxx}$ & $\mathrm{xxxx}$ & $\operatorname{xxxx}$ & $\operatorname{xxxx}$ & $\operatorname{xxxx}$ \\
\hline Constant & 2.370 & 0.829 & $0.017^{* *}$ & 10.697 & - & - & - & - \\
\hline \multicolumn{9}{|l|}{ DISTres } \\
\hline Kiambu & - & - & - & - & 0.881 & 0.278 & $0.000^{*}$ & 2.413 \\
\hline Kisumu (RC) & $\operatorname{xxxx}$ & $\operatorname{xxxx}$ & $\operatorname{xxxx}$ & $\operatorname{xxxx}$ & $\operatorname{xxxx}$ & $\operatorname{xxxx}$ & $\mathrm{xxxx}$ & $\operatorname{xxxx}$ \\
\hline \multicolumn{9}{|l|}{ INFORsource } \\
\hline ASK show & - & - & - & - & 0.532 & 0.139 & 0.187 & 1.702 \\
\hline Friends & - & - & - & - & -0.827 & 0.116 & $0.017^{* *}$ & 0.437 \\
\hline Family & - & - & - & - & -0.659 & 0.129 & $0.002^{*}$ & 0.517 \\
\hline Public forums & - & - & - & - & -0.796 & 0.244 & $0.051^{* * *}$ & 0.451 \\
\hline Bank (RC) & $\operatorname{xxxx}$ & $\operatorname{xxxx}$ & $\operatorname{xxxx}$ & $\operatorname{xxxx}$ & $\mathrm{xxxx}$ & $\operatorname{xxxx}$ & $\operatorname{xxxx}$ & $\operatorname{xxxx}$ \\
\hline \multicolumn{9}{|l|}{ BANinst } \\
\hline Equity & - & - & - & - & -0.458 & 0.165 & 0.131 & 0.633 \\
\hline Cooperative (RC) & - & - & - & - & $\mathrm{xxxx}$ & $\operatorname{xxxx}$ & $\operatorname{xxxx}$ & $\operatorname{xxxx}$ \\
\hline \multicolumn{9}{|l|}{ NUMapplied } \\
\hline More than thrice & - & - & - & - & 0.983 & 0.110 & $0.011^{* *}$ & 2.672 \\
\hline Thrice & - & - & - & - & 0.546 & 0.161 & 0.118 & 1.726 \\
\hline Twice & - & - & - & - & 0.129 & 0.110 & 0.144 & 1.138 \\
\hline Ones (RC) & - & - & - & - & $\operatorname{xxxx}$ & $\operatorname{xxxx}$ & $\operatorname{xxxx}$ & $\operatorname{xxxx}$ \\
\hline Constant & - & - & - & - & 0.757 & 0.224 & $0.016^{* *}$ & 2.132 \\
\hline
\end{tabular}

Notes. RC $=$ Reference category; ${ }^{*}$ significant at $p=0.01 ;{ }^{* *}$ significant at $p=0.05 ;{ }^{* * * *}$ significant at $p=0.1$. Source: Survey data, 2009.

Income level. Model one shows that farmers earning KES 150,000 or more were 2.7 times more likely to have successful credit request than farmers whose income was below KES 20,000 per month. When the model is adjusted for confounders, farmers in the top income scale became 2.3 times more likely to have their credit applications successful than those in the lowest income bracket. Variation between top and bottom earners is significant at 0.01 error margin. Table 6 further shows farmers in the income bracket of KES 100,000 to 149,999 were 2.1 times more likely to succeed in their applications than those earning less than KES 20,000. However, when confounders are included in the equation, the group became two times more likely to have their credit request successful than farmers in the bottom income scale. The results show that the higher the average income is, the greater the chances of farmers accessing bank credits are. The analysis indicated that Kiambu farmers in the top income group (KES 150,000+) were about 0.6 times more likely to have successful credit request than their counterparts in Kisumu. However, variation between the two groups is not significant. For the lowest income earners, Kisumu farmers earning below KES 20,000 were 0.9 times less likely to have their credit request successful than their counterparts in Kiambu. Again, the variation was not significant, implying that low income farmers in both regions are not significantly different in accessing bank credit.

Land tenure. In the first model, farmers owning land singly were 2.2 times more likely to have their applications successful than those farming on rented land. When confounders are included in the equation, the results show that farmers owning land singly were 1.9 times more likely to have their credit applications successful than farmers operating on rented land. The variation between farmers owning land singly and those practicing agriculture on rented land is significant at 0.05 error margin, implying up to 95 percent chances that 
type of land tenure significantly influences the success of bank credit request. The analysis also indicated that Kiambu farmers owning land singly were 1.6 times more likely to have successful credit request than their counterparts in Kisumu. Variation between the two groups is significant at 0.1 error margin, suggesting up to 90 percent chances that Kiambu farmers owning land singly had better chances to access bank credit than their Kisumu counterparts. Furthermore, Kiambu farmers operating on rented land were 0.3 times less likely to have their applications successful than similar farmers in Kisumu. However, variation between the two groups is not significant, implying that farmers operating on rented land had lower chances of accessing bank credit, irrespective of their residential districts.

Land size. As indicated in model one, farmers owning 2.5 to 2.9 ha of land were about 1.6 times more likely to have successful credit request than farmers owning less than 1 ha of land. When the model is adjusted for confounders, the results in model two show that famers owning 2.5 to 2.9 ha of land were about 1.6 times more likely to have their applications successful than their colleagues owning less than 1 ha, representing marginal change in the chances. Variation between the largest and smallest land owners is significant at 0.01 error margin, thus, suggesting up to 99 percent chances than small-scale farmers with 2.5 to 2.9 ha of land stood a better chance to access bank credit than their counterparts owning less than 1 ha.

In addition, model one shows that farmers owning 1.0 to 1.4 ha were 1.5 times more likely to have their credit applications successful than farmers with less that 1 ha. When the equation is adjusted to include confounders, the odds ratio reduces to 1.1 times. However, variation in the odds ratios between farmers owning 1.0 to 1.4 ha and those owning less than 1 ha is not significant. Nonetheless, the size of land owned by small-scale farmers influences the chances of their credit request being successful, thus the larger the land size is, the greater the chances that credit requests will be successful are. Furthermore, Kisumu farmers owning 2.5 to 2.9 ha of land were about 0.3 times less likely to have successful credit request than their colleagues in Kiambu. However, variation between the two groups was, however, not significant. Similarly, Kisumu farmers owning 1.0 to 1.4 ha of land were 0.7 times less likely to access bank credit than Kiambu farmers owning the same size of land. Again, variation between the two groups is not significant, suggesting that land size influences access to bank credit equally in both regions.

Farming experience. The results in model one shows that farmers with 15 years experience were 1.5 times more likely to have successful credit request than farmers with less than five years experience. Adjusting the model to include confounders, the odds ratio reduces marginally to 1.4 times as indicated in the second model. The difference in accessing bank credit between the two groups is significant at 0.01 error margin, suggesting up to 99 percent chances that the duration of farming experience influences access to bank credit. In addition, model one shows that farmers with 10 to 14 years farming experience were 1.2 times more likely to have successful credit request than farmers with less than five years experience. When the equation is adjusted for confounders, the odds ratio increases to 1.4 times, as shown in the second model. Again, variation between the two groups is significant at 0.01 error margin, suggesting that the duration of farming experience influences access to bank credit. Generally, the results show that the longer that the farming experience is, the greater the chances that a farmer's credit request will be successful are.

Marital status. Model one shows that unmarried farmers were about 0.7 times less likely to have their credit requests successful than widowed farmers. However, when the model is adjusted to include confounding 
variables, the odds ratio reduces marginally to about 0.6 times. Furthermore, married farmers were about 2.1 times more likely to have their credit requests successful than widowed farmers. When the equation is expanded to include confounders, the odds ratio increases marginally to 2.4 times as indicated in the second model. Again, variation between the two groups is significant at 0.01 error margin, implying that farmers in marriage were accessing bank credit more than widowed farmers. The analysis further revealed that single farmers in Kisumu were 0.5 times less likely to have successful credit request that their counterparts in Kiambu. However, variation in accessing bank credit between the two groups is not significant. However, between Kiambu farmers in marriage were about 1.8 times more likely to have successful credit request than their counterparts in Kisumu. Again, the variation was significant at 0.05 error margin, implying up to 95 percent chances that marital status influences access to bank credit among small-scale farmers.

District of residence. District of residence was treated as a confounding variable in the equation. The two districts covered by the study have distinct development indicators, including per capita income and longevity among others. The results in Table 6 show that Kiambu farmers were about 2.4 times more likely to have successful credit request than their colleagues in Kisumu. The variation in access to bank credit between the two groups is significant at 0.01 error margin, suggesting up to 99 percent chances that Kiambu farmers had greater access to bank credit than their counterparts in Kisumu.

Source of information on bank credit. The most important source of information on bank credit was also handled as a confounding variable to the success of credit request by small-scale farmers. In this regard, the results show that farmers who got information through Agricultural Society of Kenya (ASK) were about 1.7 times more likely to have successful credit request than farmers who received information mainly through the banks. Variation in access to bank credit between the two groups is not significant, suggesting that ASK shows played just as an important role as banks in informing small-scale farmers. Besides, farmers who received information on bank credit through friends were about 0.4 times less likely to have successful credit request than farmers who received the same information through the banks.

Variation between the two groups in terms of access to bank credit is significant at 0.05 error margin, which suggests that farmers who received information mainly through friends were less likely have successful credit application than those informed by the banks. Although most small-scale farmers have limited information about credit products provided by intermediary commercial banks, it is apparent that source of information on the same subject influences access to bank credit, as some sources such as friends may not provide accurate information. Further analysis indicated that Kisumu farmers who received information through ASK shows were 1.2 times more likely to have successful credit request than Kiambu farmers who got information through the same source. However, variation in bank credit access between the two groups is not significant, suggesting that the two are not significantly different in accessing bank credit.

Banking institution. Banking institutions vary in terms of credit management policies, which is one of the factors confounding the success of credit request made by small-scale farmers. Although the joint initiative was formalized through MoUs specifying credit terms for small-scale farmers, banking institutions modified such specifications in effort to minimize risks. In this regard, Table 6 shows that farmers applying for credit from Equity Bank (Equity) were about 0.6 times less likely to have their credit requests successful than farmers applying for the same amount of credit through Cooperative Bank (Coop). However, variation in access to bank 
credit between farmers applying through Equity and those applying through Coop is not significant, implying that there was no significant difference in the lending policies of the two institutions. The analysis also revealed that Kiambu farmers requesting for credit from Equity were 1.9 times more likely to have their requests successful than Kisumu farmers requesting for credit from the same bank. Variation between the two groups in accessing bank credit is significant at 0.05 error margin, implying up to 95 percent chances that Kiambu farmers had greater access to credit facilities provided by equity than Kisumu farmers. Furthermore, Kiambu farmers requesting for credit from Coop were 0.4 times less likely to succeed than their counterparts in Kisumu. Variation between the two groups is not significant, thus, suggesting farmers in both regions were not significantly different in accessing credit facilities provided by Coop.

Number of previous applications for bank credit. Access to bank credit may further be confounded by the number of previous requests made to the same banking institution. In this regard, the results show that farmers who had requested for credit more than thrice earlier were about 2.7 times more likely to succeed than farmers making their first requests. This suggests that the number of previous applications influences the success of current request for credit. Similarly, farmers who had made three requests previously were about 1.7 times more likely to have their credit applications successful than farmers applying for the first time. The results show that prior experience in applying for bank credit influences the chance of having a successful credit request. Furthermore, Kisumu farmers who had applied for credit more than thrice were 0.6 less likely to succeed than their counterparts in Kiambu. However, variation in access to bank credit between the two groups is not significant. Besides, Kiambu farmers who had requested for bank credit thrice previously were 1.5 times more likely to succeed than Kisumu farmers who had also made similar previous attempts. Again, variation between the two groups is not significant. This suggests that the number of previous applications for bank credit influences the success of subsequent credit request in both regions.

\section{Goodness-of-fit of the Model}

In binary logistic regression, the predictive power of a model is indicated by the change in -2 Log Likelihood (-2LL) statistic each time a variable is added into the models. Each model generates an initial -2LL (chance model), the unit change in the value of -2LL statistic also represents the proportion of variance in the predicted variable, explained by a covariate. Figure 5 shows the covariates used in this study and the proportion of variance in the success of credit request by small-scale farmers explained by each.

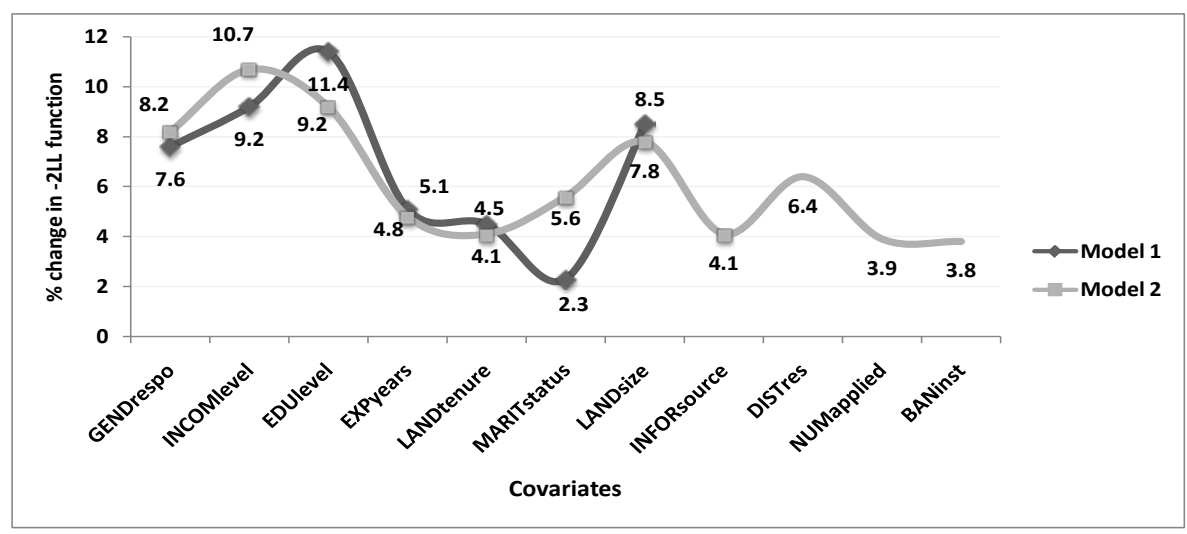

Figure 5. Effect of covariates on the success of credit requests. 
Figure 5 shows the net effects of each covariate, which have been converted into percentages. In model one, education level accounts for the highest proportion of variance in the success of credit request by small-scale farmers (11.4\%), this is followed by income level (9.2\%), land size (8.5\%), and gender of the respondents (7.6\%). The sum of proportions contributed by each covariate is 48.6 percent. This shows that model one explains up to 48.6 percent of variance in the success of credit request by small-scale farmers. This corresponds with the difference between the chance model and the final -2LL function, for which the analysis obtained a calculated $\chi^{2}$ value of 25.265, with six degrees of freedom, implying that the model is significant at 0.01 error margin.

When the model is adjusted for confounders, income level accounts for up to 10.7 percent of variance in the success of credit request by small-scale farmers, followed by education level (9.2\%), gender (8.2\%), and land size (7.8\%). The sum of all covariates totals 68.6 percent. Thus, adjusting the model for confounders increases the proportion of variance in the success of credit request explained from 48.6 percent to 68.6 percent. The remaining 31.4 percent may be accounted for by other variables not included in the model. In model two, the difference between the chance model and the final -2LL is significant at 0.01 error margin (calculated $\chi^{2}=18.134$; 9 degrees of freedom).

\section{Conclusions and Policy Implications}

The broad objective of this study was to determine factors influencing access to bank credit by small-scale farmers, focusing on the partnership initiative between GoK and selected commercial banks. The study was necessitated by lack of a comprehensive empirical investigation, documenting issues raised in anecdotal literature about effectiveness of the partnership initiative in enhancing access to credit for small-scale farmers. The study assessed various attributes of farmers, which included demographic and socio-economic attributes, as well as economic factors specific to farming practices. The analysis revealed that access to bank credit was significantly related to farmers' gender, marital status, education level, income level, type of land tenure, land size, farming experience, and number of previous credit requests. In addition, credit access was significantly associated with intermediate variables such as district of residence, banking institution, number of previous credit requests, and main source of information about bank credit services.

Regarding information sources, out of 271 farmers, 48.3 percent listen to radio, 38.0 percent watch TV, and 17.0 percent read newspapers on a daily basis, thus, radio emerges as the most important form of mass media accessible to farmers. Access to mass media is critical for information on new credit products. Farmers with frequent access to mass media channels such as radio, TV, and newspaper are likely to be more informed than those with limited or no access. Based on this premise, Kiambu farmers, with greater access to radio and TV, were likely to be more exposed and informed about the credit market than their counterparts in Kisumu. It's no surprise that in Kiambu, up to 56.3 percent of farmers requesting for credit were successful, compared with Kisumu where only 37.8 percent reported success.

The most important information sources included ASK shows (32.5\%), friends (26.9\%), and the banks (19.6\%). In Kisumu, the most important sources of information included friends (35.4\%), ASK shows (33.9\%), and banks (14.2\%); while in Kiambu, main information sources included ASK shows (31.9\%), banks (24.3\%), and friends (19.4\%). ASK shows provided a suitable forum through which farmers received information about bank credit services. However, more farmers in Kiambu than in Kisumu received information directly from the 
banks. Emerging from the findings is that little to no effort was made to popularize the partnerships initiative among farmers, particularly through the mass media. This affected the uptake of credit services, particularly in Kisumu, where its access was much lower. Although the credit facilities had been in existence for about three years, it emerged that most farmers were not aware of the initiative. Besides, due to limited publicity through radio, TV, and newspaper, the linkage between exposure to mass media and access to bank credit was not significant. However, mass media remain a key channel through which small scale-farmers can be reached with information on formal credit facilities designed to meet their needs. Informing farmers about bank credit products is particularly necessary to clear misconceptions and myths which are often associated with bank credit.

Through multivariate analysis, it was noted that Kiambu farmers were about 2.4 times more likely to have successful credit request than their colleagues in Kisumu. The variation between the two groups may be attributed to various factors, favoring Kiambu farmers, for instance, greater access to information directly from the banks, which may be comprehensive than tit bits provided during ASK shows or by friends. Besides, the variation may be attributed to difference in economic power, which may have implications on the ability to raise required collateral. With a mean income of KES 66,771, Kiambu farmers were significantly stronger economically than their Kisumu counterparts whose income averaged KES 55,654. In addition, credit requests by men were about 1.3 times more likely to succeed than credit requests by women. The variation between men and women in accessing bank credit was stronger in Kisumu than in Kiambu, implying that Kiambu women were about 4.3 times more likely to access bank credit than their Kisumu counterparts. Until recently, women have been at a disadvantaged position to access bank credit, particularly due to limited access and ownership of properties such as land and capital equipments, which can be used as collateral. Creating special credit packages for women in response to their unique socio-economic attributes, challenges and circumstances farmers may be a positive step in strengthening agriculture to effectively alleviate poverty and hunger.

In relation to education level, the study found that the higher the education level is, the greater the chances of farmers accessing bank credit are. In other words, farmers with university and college education were 1.4 and 1.1 times, respectively, more likely to access bank credit than those with no formal education. In the regions, Kiambu farmers holding university degrees were about 0.8 times more likely to access bank credit that Kisumu farmers with the same education level. In addition, Kiambu farmers with no formal education were about 1.4 times more likely to access credit than their Kisumu counterparts. Such imbalances indicate how varied access to bank credit was between the two regions. Nonetheless, pegging credit access on education level may lock out many farmers with lower formal education. In this study, up to 14 percent of the farmers had less than secondary education. Although education level is an important criterion for accessing loans, locking out many farmers with no education may limit the potential of small-scale farming in poverty alleviation and hunger reduction. This necessitates a training program on credit access and management, without which, even farmers with university education are at the risk of mismanaging credit funds.

Regional imbalances are also evident in terms of income level, where Kiambu farmers in the top income group (KES 150,000+), were about 0.6 times more likely to access credit than their counterparts in Kisumu, in terms of land tenure, Kiambu farmers owning land singly were 1.6 times more likely to access credit than their Kisumu counterparts, while in terms of land size, Kisumu farmers owning 2.5 to 2.9 ha of land were about 0.3 times less likely to access credit than their colleagues in Kiambu. Regional imbalance is also noted in terms of 
banking institutions, where Kiambu farmers requesting for credit from Equity were 1.9 times more likely to access credit than Kisumu farmers requesting for credit from the same bank. This further confirms that Kiambu farmers had greater access to credit facilities provided by equity than Kisumu farmers. Formulating appropriate internal control mechanisms is likely to minimize such regional imbalances to ensure that the initiative does not operate as a political tool.

Overall, the main factors influencing access to bank credit under the partnership initiative include income level which accounts for up to 10.7 percent of variance in the success of credit request by farmers, education level (9.2\%); gender (8.2\%), land size (7.8\%), district of residence (6.4\%), marital status (5.6\%), years of farming experience (4.8\%), land tenure (4.1\%), information source (4.1\%), number of previous requests (3.9\%), and banking institution (3.8\%). The model explains up to 68.6 percent of variance in the access to bank credit. Although the partnership initiative is an innovative approach for enhancing access to bank credit for small-scale farmers, its potential has not been fully exploited. Out of 271 applicants, only 47.6 percent managed to access credit. This means that slightly more than half of small-scale farmers may not be accessing credit under the initiative. It is important for the banks to do more than just awarding credit. Initiating appropriate measures to inform farmers and help them meet prequalification conditions will go a long way in making the initiative more responsive to financing needs of small-scale farmers.

\section{Directions for Further Research}

Commercial banks are crucial in funding economic activities in various sectors, including agriculture. In Kenya, commercial banks have not been fully supportive to small-scale farming activities. As a result, such farmers have been coping by sourcing financial support from alternative sources, albeit not sufficient to address their financing needs. This study did not assess coping measures initiated by small-scale farmers and their effectiveness. Access to formal credit services is necessary for small-scale farmers to improve their productivity by enabling farmers to afford farm inputs and technology. This study did not assess the impacts of credit access and change in production level. Future studies should consider investigating and shedding more light on these areas.

\section{References}

African Union. (2003). Assembly of the African Union: Second ordinary session. Retrieved from http://www.nepad.org/nepad/.../maputo-declaration

Agricultural Finance Corporation. (2005). Corporate strategic plan, 2005-2010. Nairobi: AFC.

Aldrich, S. T., \& Nelson, P. D. (1984). Advanced quantitative techniques for social sciences (2nd ed.). New York: Routledge.

American Statistical Asociation. (1999). Survey research methods section information. Retrieved from http://www.stat.ncsu.edu/info/srms/srms.html Accessed on 11/7/2010

ASARECA (2010, December). Facilitating collective marketing best practices in Kenya and Uganda. Agro Credit Policy Brief. Best, J. W., \& Khan, J. V. (2004). Research in education (7th ed.). New Delhi: Prentice Hall of India.

Food and Agriculture Organization (FAO). (2004). The state of food insecurity in the world 2004. Rome: Food and Agricultural Organization.

Food and Agriculture Organization (FAO). (2009). The Special Challenge for Sub-Saharan Africa. Proceedings from the 2009 High-Level Expert Forum on "How to Feed the World in 2050". Rome.

Government of Kenya (GoK). (2003). The economic recovery strategy for wealth and employment creation 2003-2007. Nairobi: Government of Kenya.

Government of Kenya (GoK). (2004). Strategy for revitalizing agriculture, 2004-2014. Nairobi: Government Printer. 
Government of Kenya (GoK). (2010). Agricultural sector development strategy 2010-2020. Nairobi: Government Printer. International Monetary Fund and World Bank. (2008). Kenya, Uganda, and United Republic of Tanzania: Selected issues. IMF Country Report No. 08/353. Washington D. C.: International Monetary Fund.

Kandinate, C, H. (2007). How accessible are agricultural loans in Kenya to local farmer. Journal of Agriculture and Social Research, 3(2), 97-107.

Kibaara, B. W. (2005). Technical efficiency in Kenya's maize production: An application of the stochastic frontier approach (Masters thesis presented at Colorado State University, USA).

Kibaara, B. W. (2006). Rural financial services in Kenya: What is working and why? Tegemeo Working paper 25/2006. Njoro: Tegemeo Institute of Agricultural Policy and Development.

Mugenda, O. M., \& Mugenda, A. G. (1999). Research methods: Quantitative and qualitative approaches. Nairobi: Acts Press.

Mwangi, H. (2008). Strategies for deepening and broadening client base: A case of AFC Kenya. Experience in reaching small-scale entrepreneurs through innovations in microfinance. Paper presented at the 5th AFRACA Microfinance Forum, Cotonou-Benin.

Nachmias, C. F., \& Nachmias, D. (1996). Research methods in the social sciences (5th ed.). London: Arnold.

New Partnership for African Development. (2009). How are countries measuring up to the Maputo declaration? Policy Brief. Midrand, S.A.: NEPAD Secretariat Agriculture Unit.

Odhiambo, W. (2007). Financing African agriculture: Issues and challenges. Draft paper to be Presented at the Second African Economic Conference at the UNCC, Addis Ababa, Ethiopia.

Pearce, D. (2004). Making rural finance count for the poor, agriculture and natural resource team. UK: DFID.

Ravallion, J. C. (2001). Issues and experience in agricultural financing in Africa: Lessons for policy. Journal of Agriculture and Social Research, 12(1), 1-23.

Rindfleisch, A., Malter, A. J., Ganesan, S., \& Moorman, C. (2008). Cross-sectional versus longitudinal survey research. Journal of Marketing Research, 45(3), 1-23.

Stamoulis, K. (2007). Rural development and poverty reduction: Is agriculture still the key? ESA Working Paper No. 07-02. Rome: Food and Agricultural Organization.

United Nations Development Programme and Government of Kenya. (2008). Human development report 2008. Nairobi: UNDP/GoK.

World Bank. (2007). World development report 2008: Agriculture for development. Washington D. C.: The World Bank.

World Bank. (2008). The growth report: Strategies for sustained growth and inclusive development. Washington D. C.: Commission on Growth and Development, World Bank. 